\title{
Significance of Parental Influence on School Growth and Population in African Contexts
}

\author{
Ajani OA $^{1 *}$ and Dosunmu $\mathbf{S}^{2}$ \\ ${ }^{1}$ Department of Curriculum and Instructional Studies, Faculty of Education, University of Zululand, South Africa \\ ${ }^{2}$ Department of Educational Foundations and Counselling Psychology, Lagos State University, Nigeria
}

\begin{abstract}
This study explored the roles of parents in choosing schools for their children which adversely affect the growth of schools in African nations, using Nigerian contexts. There has been a massive awareness on the part of the parents to give quality education to their children at affordable costs. This is based on the general belief that education is a significant means of liberating and empowering family members for better lives. This study delved into reasons why parents preferred one school to another for their wards in African countries. The motive of this paper was to make empirical submission on the patronage of schools in Nigeria. Rational choice theory, market theory and choice theory were used as frameworks to underpinned this study. This quantitative study used 100 senior secondary school students and 100parents from Lagos, Nigeria as participants through the stratified sampling procedure. The validity of the instrument was tested using the expert opinion method while the reliability was tested with a test re-test method which indicated a co-efficient of 0.71 . The correlation co-efficient method was used to analyse the collected data which was five percent significance, all the five hypotheses were equally tested to ascertain the claims. The study revealed statistically significant factors such as parents' influence, socio-economic and educational background, parents' desires for good education for their children, adolescents' academic performance, parents' quests for the best education for their children and cost of education. Recommendations were made to advise the priorities among these factors.
\end{abstract}

Keywords: Significance; Desires; Achievement; Responsiveness; Quality of education

\section{Introduction}

Education is the bedrock of development of any nation [1]. Nations are made up of families. Education of young members of the families have become health competitions among families. Every family wants the children to acquire education based on what they can afford and also worthy of the value. These ideas have led to parents using different measurement to determine schools their children will attend. Careful examination of how and why parents choose particular schools for the children in different parts of Nigeria will reveal the variety of yardsticks parents use to choose schools for their children.

Various determinants are responsible for their final discussions on which educational institutions their children would attend. Education today, is an important medium of empowerment for the children. It provides the learners with variety of specialized skills and knowledge that can make them responsive members of the societies while at the same time, provides them with means of livelihoods though jobs. Schooling is widely acknowledged as a major investment in human capital that enhances career opportunities and wages. It has been discovered by many parents today to have been an avenue for escaping poverty and to reduce income inequality in an economy. Education gives learners the opportunities to earn social class and economic stratification. Parents therefore enrol their children in schools that can give them expected quality of lives [2].

Education is an investment to better living and also improved economy of a country; this helps to liberate most families from the shackles of poverty. It is also education that propel and sustain the level and pace of development in any country.

\section{Theoretical Framework}

Education is significant to professional development of individuals in the economic development of every nation, it propels the growth of economic structures to meet up with the economic demands and aspirations of the country. Every skilled profession requires improvement on the professional abilities and functions of the professional in the profession. It the education that makes production of goods and services to be improved to acceptable level of quality by the producers and consumers of such products and services [3]. As a matter of fact, education is significant to development, development is key determinant to technology usage and capacity. Based on the critical roles of education in the development and technological advancement of any society, parents are meticulous in selecting schools that can make or mar their ambitions of having responsive children who will also be financially capable to care for them in their old age in Africa. The selections of their choice of schools were underpinned with various theories [4].

\section{Rational choice theory of school choice}

Hargreaves and Fullan reported that parents play significant roles in schools' development and improvement in schools' reformation initiatives, they were usually considered in introductions of innovations or ideas into the school structures. Improvement of school services to accommodate more learners and also to strengthen the existing schools services were the basis for establishment of private schools, these acts involved active participations of parents and community

${ }^{*}$ Corresponding author: Ajani OA, Department of Curriculum and Instructiona Studies, Faculty of Education, University of Zululand, South Africa, Tel +27 35902 6950; E-mail: Oaajani@gmail.com

Received April 25, 2018; Accepted May 01, 2018; Published May 07, 2018

Citation: Ajani OA, Dosunmu S (2018) Significance of Parental Influence on School Growth and Population in African Contexts. Arts Social Sci J 9: 365. doi: 10.4172/2151-6200.1000365

Copyright: @ 2018 Ajani OA, et al. This is an open-access article distributed under the terms of the Creative Commons Attribution License, which permits unrestricted use, distribution, and reproduction in any medium, provided the original author and source are credited. 
for learners' academic improvement. Schools need to be aware that Parents' perception and patronage of their schools are affected by the rational choice theory, parents don't just make choice but think about the rationale for choosing the schools, their actions are based on the pros and cons of their choice of school A over school B, in terms of the benefits and the costs of educating their children in such schools $[5,6]$.

\section{Market theory of school choice}

Market theory is another theory that affects the growth and population of schools; schools are made to engage in various acts of competitions to outshine one another [7]. Various initiatives, activities, services and programmes are introduced to attract parents' patronage in the schools; their varieties promote effectiveness of the school system and increased productivity. Choice of schools allow parents to choose their needs, values, and interests as social units of the societies, thereby promote the education system, and provide leverage for middle income parents to empower their children with desired quality education that raise their standard of living [8].

Research studies have shown that choice of schools for children as made by parents overrides the school' economic return on their investments. Selection of schools is a social process that is greatly influenced by the parental social class and relationships. Coleman explains making cogent decisions that have to do with choice of schools for children by their parents, the parents needs to depend on information from professionals and social networks to arrive at benefitting decisions based on rationalities [9].

Parents need relevant and varied information on schools to be able to make their choice on schools for their children, hence, parents inability to meet with many sources of valuable information are incapacitated to make valid decisions from available limited choices of schools. Assumptions have always been the basis for most of the research studies on the choice of schools by parents for their children, however, empirical evidence are needed to substantiate the claims. Emphasis has been placed on the interrelationship between how schools are governed and their productivity. Empirical result showing higher enrolment of learners in public schools as against the ones in private schools should not be basis but the level of learners' competencies in the subjects should be the concerns [10]. Increasingly, there has been a body of research studies focusing on the various schools' reforms and the impact on learners; abilities or characters.

However, there remain some aspects that cannot be measured but which families use their own discretions to determine in selection of schools for their children [11]. Parents also consider their own level of education, availability at home to support such children's education, societal and environmental activities are all contributory factors.

\section{Theory of planned behavior (TPB)}

Ajzen, Fishbein developed theory of planned behavior which reflect on the parental behaviour on the selection of schools due to their attitudes, their perceptions and what they can actual afford in education of their children. This behaviour is planned for execution only if they can afford despites the huge benefits of the schools, parents can only enroll their children in schools that they can afford, pressures from others factors cannot be used to change their decisison. The theory is also applied to other areas of their lives to determine their behaviours [12].

Parents across Australia have options of enrolling their children in any government or independent schools of their choices. It is believed that the government schools have the largest population with largest patronage from parents in Australian communities, this is put at $68 \%$ of total population of students. Tides however turned between 1979 and 2004 when the independent schools witnessed increased in number of students' enrolments over the government schools with about $11 \%$ increment resulting into 4,59000 students,. Increment in the enrollment numbers of these independent schools showed a paradigm shift in parents' reasons of selecting schools for their children to push for better education that can be afforded by them. The power to choose schools in Australia invariably affect the market shares of enrolment between the government and independent schools [13]. The competition for increase in school population and sustenance of school population depend on marketing strategies that schools adopt to attract parents' patronages in Australia. Schools need to understand what parents are looking for in schools and how they can make these available to entice or attract them. The attraction revolves around what parents want in schools for their children to attend such schools. Research studies are carried out to unravel what can attract parents to enroll their children in particular schools [14].

Various research investigations have been done, using different approaches and using different samples to generate determinants of choice schools for parents in the sampled locations [15]. These report include quantitative approach in government reports that adopt survey approach which generated 29 various and cogent factors prominently among them are the ethnic/racial based schools that can motivate parents' enrolment of their children in schools. Goldring and Hausman structured the factors into 16, this was further categorized into 4 key areas namely: academic performance, convenient location, discipline and the community value on the schools [16]. Significantly, the convenient nature of the government schools made parents to prefer enrolments of their children in government owned schools while the academic performance of the independent schools were the reasons for patronizing the independent schools. Denessen in a similar research arrived at 17 factors that attract parents to enroll their children in different schools; the most driving factors were adherence of the school to their religion practice and beliefs, social background/ environment and ethnical influence on the children [17].

Other research studies differ on the above identified factors. Elacqua in their study of 530 sampled parents though questionnaire, arrived at 8 findings for parental reasons for choosing schools for their children. These are school academic achievement, location, affordability of the cost, safeness of their children, classroom sizes, available facilities, moral integrity and school discipline [18]. Bussell in his qualitative study of 20 semi structured interviews with parents generated 31 reasons with the most primed one to be the learners' happiness in that particular chosen schools. West generated 22 reasons with the academic standard and performance of the schools as the first reason why parents choose schools for their children from his qualitative study with 70 sampled parents he interviews and identified. Schneider, Buckley stated in their education website, 9 reasons based on what they observed from the parents to be class sizes, location, academic performance, quality of staff, available facilities, academic programmes, after school services, extra-curricular activities. Another prominent group of researchers arrived at various reasons why parents enroll their children in schools [19]. Kleitz in their qualitative research study of 1100 sampled parents using 5 item interview guide on why parents choose particular schools for their children, attained location, class sizes, educational standard, safety of the children and presence of family and friends in the schools to be their reasons of enrolments. 
Kleitz findings agree that preference of parents for academic standards do no differ from various ethnic parents or social class, all parents demand for quality education as what they cannot compromise for anything. Jackson and Bisset in their longitudinal study of 225 parents anchored on academic performance of the schools, and the school reputation to be the pressing factors [20]. There are many reasons that can still be investigated for the reason of enrolments in schools by the parents of their children apart from the limited findings of various studies.

\section{Choice theory of school choice}

Training of children entails so many things and schools are always looked upon by parents as good mechanism to help discipline children, this is why parents consider as important factor in choosing schools for their children, parents look for schools that can help give good up bring to their children. Choice theory enables parents to choose schools that will promote acceptable disciplinary measures on their children without being questions by the children, they want children to accept correction without being engaged in argument as to why they need to be corrected. Parents are comfortable to send their children to schools where children we have no options to discipline at home or to query their orders. Parents want choice theory where children's choices or options are for display of good behaviours and conformity with societal norms and values which make them fit into the society. The choices or options also make the children to use wisely their rights [21].

Delving into the world of discipline, children feel better when they are given choices or options in expected behaviour or punishment for deviant behaviour. Choice theory in this manner, helps the children to be responsible for their actions and to face consequences of their actions. No matter how hard the consequences may be. The schools need to play a vital role in making the children to understand this and how to act best to avoid conflict of interest and to be accountable for their actions and behaviours.

\section{Parental Overview of Nigerian Education System}

A careful in-depth of schools' patronage and reasons for growth of schools in Nigeria, especially Lagos State with reference to selections of choice schools for children would reveal so many factors or determinants that affect parents' choice of schools for their adolescents in Ojo Local Government area of the state. Choice of schools varies between private and public schools, and also among private schools or public schools.

Some parents prefer public owned schools for their children, while others go for private schools. Many reasons have made some parents to choose private schools against public schools. Ajayi pointed out that education system in Nigeria has come under various challenges that have made parents to be so selective in schools for their children, this has further led to parents' inability to be primarily concerned on why the children must be educated in some instances [22]. Nigerians in the educational system seem to have overlooked the primary purpose of schooling and of the high expectations and disciplined effort needed to achieve them. Okafor claim that parents are losing interest in public schools based on the falling standards of education.

The system is facing some challenges especially in public schools where the facilities, quality of teaching and other things are challenging the public schools in Nigeria. Other identified problems are classroom sizes know to be overcrowded, in adequate number of teachers, inadequate facilities, incessant academic strikes amongst others.
Nowadays, Parents are in search of quality education that is affordable and can meet their expected desired for their children. Parents have discovered education to be a medium of liberating the family from shackles of poverty, they look for schools that can give quality education at affordable costs. It is imperatively becoming order of the day in most families to give it all it takes to educate every members of the families, more graduates are produced in family to close illiteracy gaps in the families.

As a results of various challenges public schools are witnessing, parents are embracing opportunities being provided by private schools. This embracement has further led to massive growth of private schools in different parts of Nigeria. Private schools are rising in numbers. School business is one of the most lucrative businesses in Nigeria today, people will not stop giving birth, and children need to attend schools for education, this is why the business continue to enjoy major patronage. Every private school has its own target and based on the shortcomings of the public schools in Nigeria, parents are turning to private schools for enrolments of their children. It is also a known fact that there is limited number of public schools in Nigeria, and only Government cannot cater nor meet educational needs of the parents in Nigeria, hence, there is need for private participation. Government is also encouraging private participation in education system so as to cater for the mass populace and to achieve education for all policy. It is also a fact that despites all the challenges public schools are facing, some parents still believe in public schools and will always prefer their children to attend public schools based on their own reasons.

Private schools in Nigeria have gone through stages to be relevantly and prominent sector of education system in Nigeria. They have enjoyed patronage and recommendations from parents and even government authorities for many decades. This has brought about staff competitions between public schools and private schools, and also among private schools. Various determinants have been established by experts who have worked on related topics on choice of schools for children by their parents or guardians. Knudson declares that implementation of school curriculum is better achieved and delivered in the private schools than public schools. His argument was that students in public schools do not enjoy quality teaching that actually make teaching to be concrete and practical to them, and their progression from one class to another can be massively with porous academic measurement and standards.

Cost effective is also a determinant for parents' preference for choice of school for their adolescents. The Human Development Network of the World Bank agreed education is cost effective in private schools than the government schools. It is true that students pay higher tuition fees in private schools than public schools but the cost of operating private schools are lower or cheaper than that of public schools due to students - teacher ratio and salary structures. Outputs from schools is another important factor, output from schools describe how better and of a higher quality than others.

Knudson supports the fact that students in private schools are taught to be more respectful to elders unlike their counterparts in public schools, the students also have opportunities to be highly skilled in comportments and relationships to others in the societies. In contrast, Rothstem argue that the aim of private schools was not to produce students who can be of high inputs into the societies unlike the public schools that aim to. Consequently, products from private schools are in no way better than the students from the public schools.

Adejuyigbe claimed that locational patterns or attributes of schools regarding how easily the family members can access the schools 
are usually considered before parents can enrol their children in those schools [2]. Arabshebani agrees that the family background is important to selection of schools by the parents. The level of education, a parent has affects his decision for his/her choice of schools for his/her children for schooling.

Worpole said that child's gender is a determinant some parents use in choosing schools for their adolescents. Some parents are comfortable sending their girl-adolescents to girls' only schools while boys are preferred in boys' only schools by some parents. West Hind support that the presence of other members of the children family in schools influence the parents to enrol their children in such schools. Furthermore, parents are comfortable sending their adolescents to schools their other siblings attend to ensure their keep eyes on one another and care for each other. Parents behave that older ones can take care or monitor their younger siblings in same schools.

Bagley explained that race of the child is a factor to consider by parents in selecting schools for their parents. In Nigeria context, some parents are tribalistic. They send their children to schools where majority of their tribe children attend, i.e. Igbo dominated schools, enjoys patronage from Igbo people while Yoruba dominated schools enjoy same. Ownership of schools is also considered, schools owned by Igbo tribe, enjoy patronage from fellow Igbo people.

Mori aptly described that schools with better or more committed teachers enjoy more patronage from parents. Parents' preferences for schools are influenced by better or more committed schools have. They compared schools on this basic before they decide for schools for their adolescents. The quality of education schools offer differentiates schools from one another. West said that quality of education offers by schools affect the enrolling figures of students in their schools. Schools with high quality education will be more populated than schools with low quality education.

Child education in Nigeria, especially in Lagos has been taken serious by all parents, both literate and illiterate parents; it is the dream of every parent in this modern day, to see their children educated and achieving success in academic pursuits. It is the parents' value for education that motivate the enrolment of their children in schools that can satisfy their dreams. Choices of schools are polarized into either public or private schools. Various factors influence their choice. Sometime schools are changed for their children when their expectations or factors that attracted them to that particular school are not met or below their ratings.

Moral education takes paramount priorities among parents; every parent wants his/her child to be morally relevant to the society he/ she belongs. Society can only accommodate children who are morally upright so as to enable peace in the locality. Religion is an agent of instilling morals in children, this is the core reason why many religious bodes set up education institutions. These schools enjoy patronage from patents that belong to these bodies or believe in the tenets of these religious owned schools. As part of their academic programmes, moral education remains part of academic programmes, students are exposed to.

Le, Miller highlighted the choice for schools' selection for children who were born between 1961 and 1970 in Australian schools and concluded that socio economic factors aided enrolment in independent schools than the government schools. Dustmann and Drnakova acknowledged parental educational backgrounds, their social classes, tastes for quality, and beliefs in the schools to be the main concerns of parents. Some parents in Lagos, especially Ojo Local Government Area enrol their wards in schools owned and run by Christians or
Muslims with key emphasis on religious doctrines and tenets. Most common among parents' factors for selecting schools is the results of schools - academic performance of students in the schools' external examinations such as SSCE, UTME, etc. in Ojo town, Lagos. Quest for academic performance of their children in such examinations that will save the parents of unnecessary expenses of re enrolling the children for the examinations remains the yardsticks of enrolling the older children in secondary schools to convince them of better academic standards of schools.

Parents are also comfortable when the older siblings of their children have been in the particular schools and they freely enrol the younger ones there to watch over the young ones. This also makes it easier for them to come home together after schools. West, Hind agree that the presence of the older siblings is highly important among parents in England, they select schools based on this factor for their children.

Affordability of the tuition and other fees remain constant in the selection of schools for children in Nigeria. Parents want to select schools that they can afford for the children. Different fees are charged by both private and public schools, hence, parents need to know the schools that they can conveniently pay for, without stressing themselves or children' education being disrupted. Choice of schools also changes when the required fees are increased or parents are unable to pay within the stipulated periods.

Crops of teachers speak out the quality of education to expect in the system. Schools with highly qualified professionals attain and maintain high academic excellence in all academic performance of their students. Parents make their enquiries through interactions with teachers or families or friends who can give them profile of teachers in schools before they enrol their children. Teachers are significant to the quality of education in any school. No school can be greater than the quality of teachers there. When the quality of education drops in schools, parents are aware and they quickly make their decisions; withdraw and enrol their children in another schools that can give them what they want in education. Facilities available in schools usually attract patronage of schools by parents. Parents assess facilities that are available in choice schools to determine enrolment of children in such schools. Facilities in schools differ. These are used to lure parents to enrol their children/ wards into schools. Notable among the facilities is computer education. Parents are attracted to schools where students are exposed to intensive computer education.

Parents can also prefer to enrol their children based on the proximity of the schools. Parents are concerned on the locations of schools in the environments. Schools in the urban areas with regular and adequate basic amenities enjoy large patronage from parents. Schools in the rural locations may not be as populated as those in the urban, the schools in the rural will have to go extra miles to provide amenities like the ones in the urban to also draw many rural children to their schools. This is clearly and evidently the case in differences in enrolment figures of children in rural and urban based schools in Nigeria as a whole.

Research evidence shows that the choices of schools for adolescents by their parents are determined by a contribution of many determinants for such parents' preferences. West suggested an investigation into factors such as:

- Quality of Education

- Family Tradition

- Academic ability of the child 
- School's expectations

- Better facilities

- Resources

- Discipline

- Good examination results

Mori in a similar study, identifies six determinants of parents' preferences to be:

- Smaller Classrooms

- Higher Standards

- Better Facilities

- Good Sports Facilities

- Wider Curriculum

- Better or more committed teachers

Selections are based on circumstances that influence or determine. It is a sum total of all social, physical, economic factors that affect adolescent schooling.

Erickson submitted that parents choose schools for their academic and curricular emphases, discipline and safety; while Buddin, Cordes and Kirby argued that, as family income and parents' level of education rise, so does the prosperity to choose a private school.

\section{Research Methodology}

This research adopted the survey research design. This is justified in its ability to make it possible for the researcher to cover a larger percentage of the subjects within a short period. It was employed because of its flexibility ability to give room for having direct relationship with the subjects. Furthermore, the survey research design elicits data directly from the field through the respondents within a relatively short time frame.

\section{Population of the study}

The targeted population for this study is the entire parents and students of public and private secondary schools in Ojo local government area of Lagos State.

\section{Sample and sampling technique}

Participants were drawn from among parents in Ojo and students from ten senior secondary schools, leading to five public secondary schools and five private secondary schools within Ojo Local Government Area. In each school, ten students/ten parents were selected using convenience sampling technique, thus a total of one hundred parents and one hundred students constituted the participants for the study, giving a sample size of 200 .

\section{Results}

Table 1 show that male respondents accounted for 65 percent while the female respondents were 35 percent. This gives a 2.1 ratio for male to female respondents.

Table 2 shows that $45 \%$ of the respondents belonged in the $31-40$ age range, 24 percent was recorded for age range 21-30 years, 15 percent for the above the age of 50 years, 10 percent for 41-50 years of age and only $6 \%$ of them belonged to the $<20$ age range. The implication of this study is that majority of the respondents are active and young.
Table 3 shows that 62 percent of the respondents are married, 26 percent are single, 20 percent are divorced while 10 percent are either widow or widower. It was therefore concluded that majority of the respondents are married and mature.

Table 4 shows that $61 \%$ of the respondents possess NCE/OND certificate, $25 \%$ have degree/higher diploma, $10 \%$ have level certificate while $5 \%$ others have second degree or more. The table shows that majority of the teachers are with higher qualifications and are professionals.

Table 5 shows that the experience of the respondents varies from low to high. 38 percent of them have 16-25 years of experience, 30 percent of them had between 0 and 5 years of experience, 19 percent were of experience range of 25-35 years, while 13 percent had between 6-15 years of job experience. This implies that majority of the respondents are experienced and versed in their job.

\section{Hypothesis testing}

Hypothesis one: There is no statistically significant relationship between parents' preference and choice of schools for adolescent (Figure 1).

\begin{tabular}{|c|c|c|}
\hline Sex & Frequency & Percentage (\%) \\
\hline Male & 130 & 65 \\
\hline Female & 70 & 35 \\
\hline Total & 200 & 100 \\
\hline
\end{tabular}

Table 1: Sex distribution of respondents.

\begin{tabular}{|c|c|c|}
\hline Age (years) & Frequency & Percentage (\%) \\
\hline$\leq 20$ & 12 & 6 \\
\hline $21-30$ & 48 & 24 \\
\hline $31-40$ & 90 & 45 \\
\hline 4150 & 20 & 10 \\
\hline Above 50 & 30 & 15 \\
\hline Total & 200 & 100 \\
\hline
\end{tabular}

Table 2: Age distribution of respondents.

\begin{tabular}{|c|c|c|}
\hline Marital Status & Frequency & Percentage (\%) \\
\hline Married & 122 & 61 \\
\hline Single & 52 & 26 \\
\hline Divorced & 4 & 2 \\
\hline Widowed & 22 & 11 \\
\hline Total & 200 & 100 \\
\hline
\end{tabular}

Table 3: Marital status of respondents.

\begin{tabular}{|c|c|c|}
\hline Variable & Frequency & Percentage (\%) \\
\hline Level & 20 & 10 \\
\hline NCE/OND & 122 & 61 \\
\hline Degree/Higher diploma & 50 & 25 \\
\hline Other & 8 & 4 \\
\hline Total & 200 & 100 \\
\hline
\end{tabular}

Table 4: Educational qualifications

\begin{tabular}{|c|c|c|}
\hline Variable (yrs.) & Frequency & Percentage (\%) \\
\hline$\leq$ to 5 & 58 & 29 \\
\hline Jun-15 & 26 & 13 \\
\hline $16-25$ & 76 & 38 \\
\hline $26-35$ & 40 & 20 \\
\hline Total & 200 & 100 \\
\hline
\end{tabular}

Table 5: Working experience of the respondents. 


\begin{tabular}{|l|l|l|l|l|l|}
\hline Variables & N & Mean & SD & R & P \\
\hline Parents' Preference & 200 & 41.29 & 7.05 & 0.794 & 0.000 \\
\hline Choice of School & 200 & 39.39 & 9.98 & - & - \\
\hline
\end{tabular}

The table is represented graphically as thus:

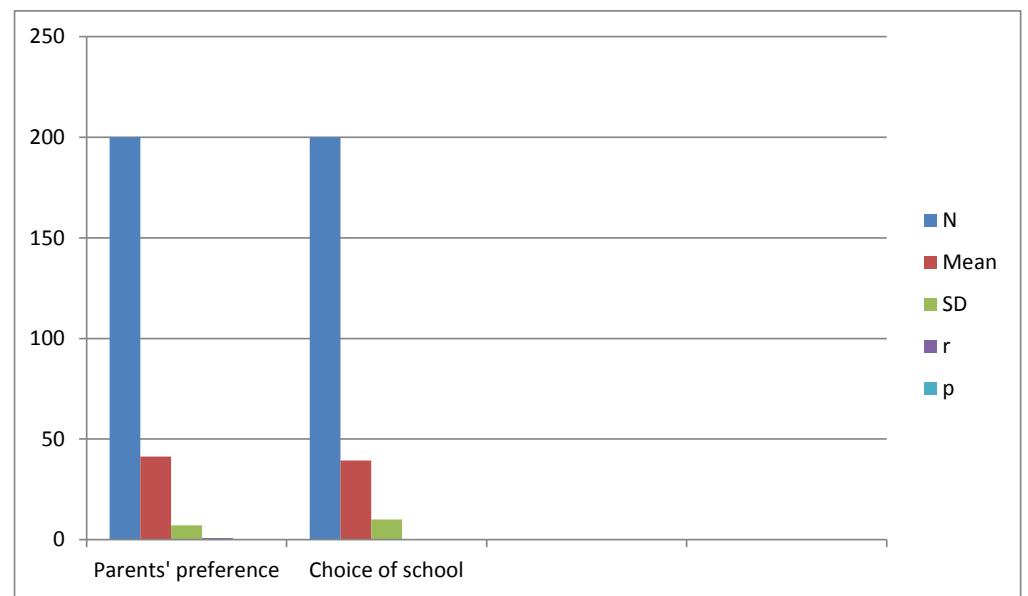

Figure 1: Correlation between Parents' Preference and Choice of Schools for adolescent.

\begin{tabular}{|l|l|l|l|l|l|}
\hline Variables & N & Mean & SD & R & P \\
\hline Socio Economic Back groung & 200 & 113.06 & 19.05 & 0.19 & 0.005 \\
\hline Choice of School & 200 & 98.11 & 15.98 & - & - \\
\hline
\end{tabular}

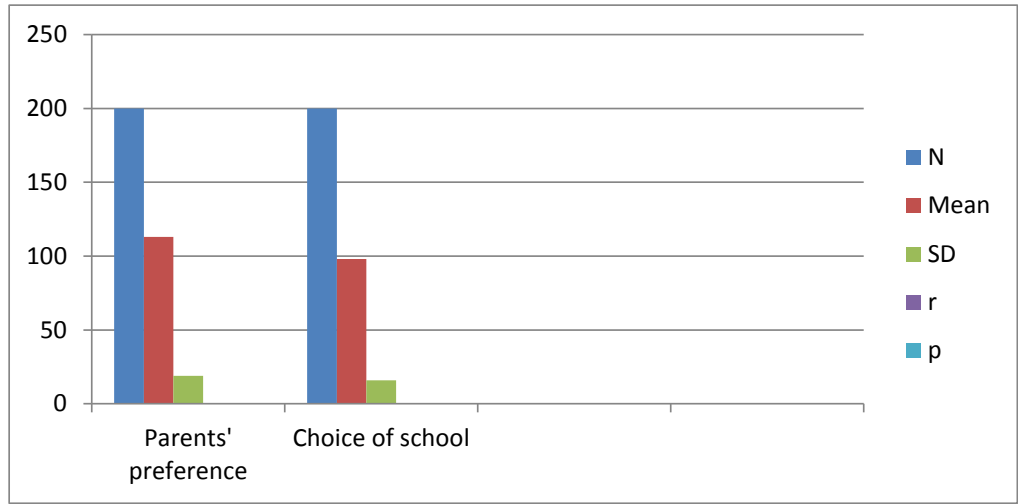

Figure 2: Correlation between socio-economic background of parents and their choice of school for their Adolescents.

The computed correlation coefficient shows that $r$ is 0.794 . The observed probability level of significance is $0.000,(p<0.05)$. This translates to ssignificant relationship between parents' preference and selection of schools for their children. The hypothesis is therefore rejected.

Hypothesis two: There is no statistically significant relationship between socio-economic background of parents and the selection criteria for schools for their children (Figure 2).

The computed correlation coefficient shows that $\mathrm{r}$ is 0.019 . The observed probability level of significance is $0.005,(\mathrm{p}<0.05)$. The table relates the significant interaction between parental socio- economic class and the reason for selecting particular schools for the children. The hypothesis is therefore rejected.

Hypothesis three: There is no statistically significant relationship between parental educational dreams and the selection of schools for their children (Figure 3).

The computed correlation coefficient shows that $\mathrm{r}$ is 0.089 . The observed probability level of significance is 0.002 . From the table, it is established that strong link exists between parental educational dreams and the selection of schools for their children. The hypothesis is therefore rejected.

Hypothesis four: There is no statistically significant relationship between parents' choice of schools and adolescents' performance in those schools (Figure 4).

Figure 4 shows that there is a significant difference in the reading habits of public and private schools $[t(198)=5.69 ; \mathrm{p}<0.05]$. This significant difference can be observed in the mean where public schools participants scored higher $(\bar{X}=142.37)$ and private schools 


\begin{tabular}{|l|l|l|l|l|l|}
\hline Variables & $\mathbf{N}$ & Mean & SD & $\mathbf{R}$ & $\mathbf{P}$ \\
\hline Educational Aspiration & 120 & 130.00 & 50.52 & 0.89 & 0.002 \\
\hline Choice of Schools & 120 & 118.92 & 43.61 & - & - \\
\hline
\end{tabular}

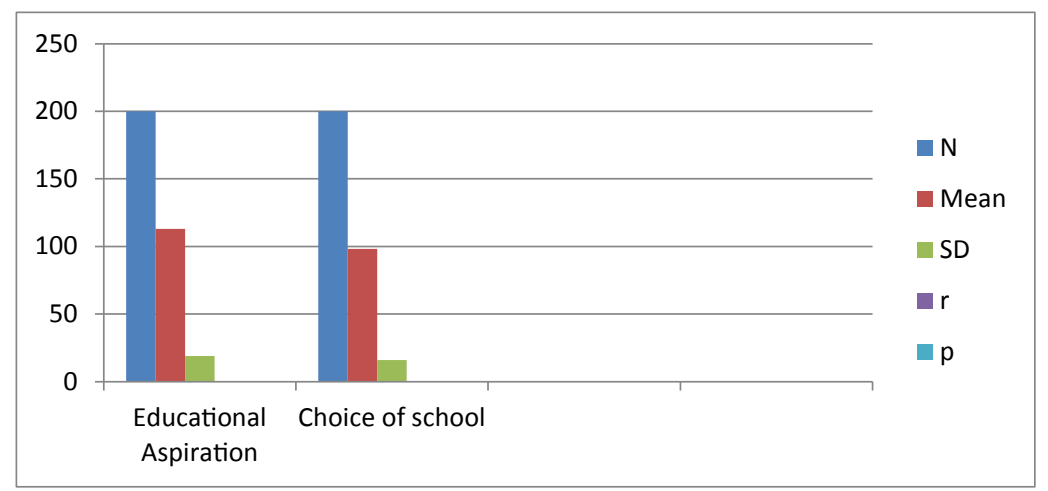

Figure 3: Correlation between parental educational dreams and the selection of schools for their children.

\begin{tabular}{|l|l|l|l|l|l|l|}
\hline Variables & N & Mean & SD & DF. & t & P \\
\hline Publics Schools & 100 & 142.37 & 15.12 & 198 & 5.69 & 0.008 \\
\hline Private Schools & 100 & 132.17 & 23.56 & - & - & \\
\hline
\end{tabular}

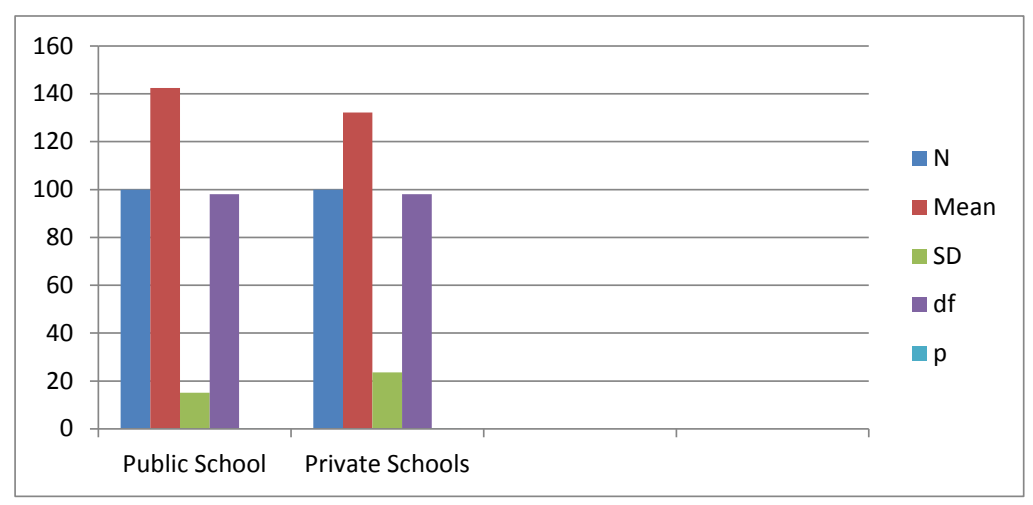

Figure 4: Difference in the choice of schools and adolescents' performance.

counterparts with lower score $(\bar{X}=132.17)$. This is interpreted to be strong influence of parental selection of schools on the academic performance of children in the schools. The hypothesis was therefore rejected.

Hypothesis five: There is no statistically significant relationship between parents' expectation or quality of education and choice of school as related to cost of education (Figure 5).

The computed correlation coefficient shows that $r$ is 0.056 . The observed probability level of significance is $0.002,(p<0.05)$. There exists a relationship between influence of parents on the selection of schools for their children and the selected schools based on the cost of education. The hypothesis is therefore rejected.

\section{Discussion of Findings}

According to the analysis of hypothesis one, it was revealed that there is a strong relationship between influence of the parents and the selection of schools for their children. This outcome is in tandem with the work of Falana who reported that the choice of schools of adolescents is mostly influenced by their parents. However, it was in contrast with the work of Bolade who reported a contrary finding. He noted that in some climes, the academic performance of students determines their choice of school.

To add to this, the second hypothesis analysis established that there is a statistically connection between socio-economic and educational achievements of parents and their selection of schools for their children. This agrees with Kolade who claims that family incomes determine to a large extent selection of schools for members of the family by their parents. Therefore, the parents are limited to schools they can afford economically despite their educational dreams for their children. This outcome as depicted by the analysis of hypothesis three is in agreement with the work of Kolade. He reported further that the educational attainment of parents is a significant factor in determining the choice of school for their adolescents.

Another finding from this work showed a statistically significant relationship between parents' choice of schools and adolescents' performance in those schools. This outcome point to the fact reported in the work of Falade who emphasised that choice of schools affects 


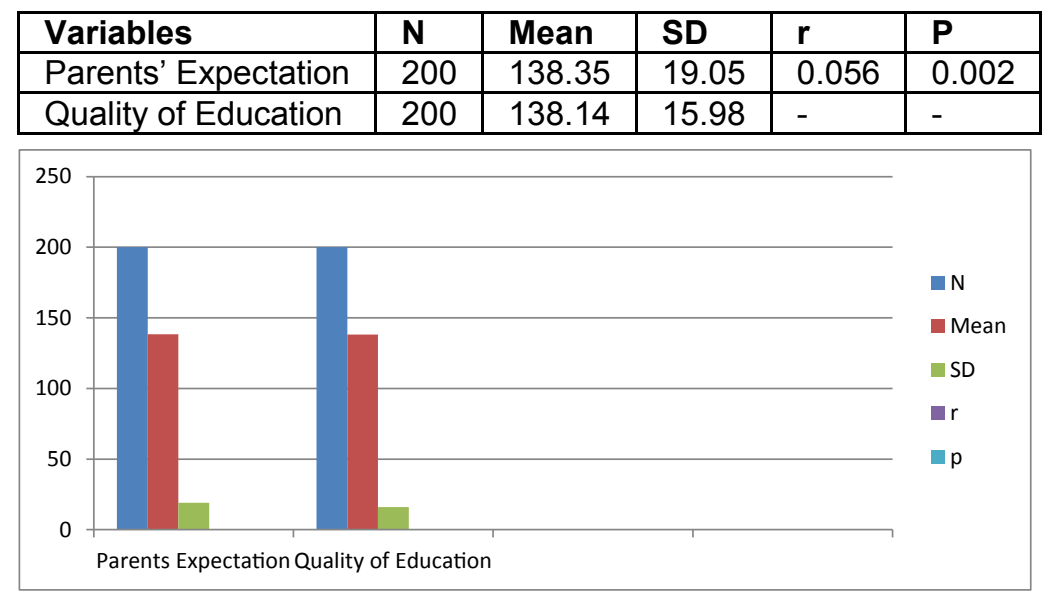

Figure 5: Correlation between parents' expectation or quality of Education and choice of school.

adolescent academic performance. Finally, the expectation of parents is a significant factor in the placement of adolescents in schools. This ascertains that parental educational dreams for their children depends on the selected schools they can afford.

\section{Conclusion}

It can be conclusively established that so many factors affect parents' selection of schools for the children in Lagos, Nigeria. This study has established the varieties of factors that affect parents in selecting schools for their children in different parts of Lagos, Nigeria between private schools and public schools. Ajayi submitted that public schools are confronted with many limitations that affect quality of education which many parents seek for their children and push them to private schools to look for quality education [1]. This nagging challenge faced by the education sector leads to inevitable consequences as observed by Okafor, "falling standards leading to pushing the goal excellence to the back burner as public confidence in our educational system is eroded."

Other important reasons for loss of confidence in our public school system include poor planning and consistent lack of investment in the education system. This has led to a near collapse of the system learning the educational infrastructures in an appalling and dilapidated state. A casual visit to any public school in Nigeria would reveal the extent to which these educational institutions have decayed. Educational facilities at all levels are in a terrible shape; schools are littered with battered structures, worn out equipment, raggedy classroom buildings, overcrowded classrooms, inadequate manpower in quantity and quality; instability in the academic calendar owning to incessant strikes, very low teacher morale due to poor remuneration and working conditions.

Based on the public schools' limitations which many government authorities yet to fix to attract most of the private school seekers parents, the parents keep patronizing the private schools to fulfil their quality education desires for their children in Nigeria.

\section{Recommendations}

Since it was discovered that there is a statistically significant relationship between what parents want in schools and available schools for their children, parents are therefore advised to know the needs of their children and select schools based on the educational fulfilments. When this is done, the educational aspirations and yearnings of the adolescents would be met. It is further suggested that parents' preference should be set not clash with the interest of the adolescents

It was also discovered that there is a statistically significant relationship between parents' educational aspiration for their children and their choice of schools for their children, therefore apart from school choice, parents should endeavour to prepare their adolescents for their desired academic aspirations in order to complete it with school choice when they grow up. Parents should endeavour to take the best samples of schools before settling for their choice. It is also recommended that since schools run different curriculum and are of different models, proper findings must be done by the parents in order to satisfy their aspirations. Government should maintain strict standard and proper regulations; improve on monitoring of public schools in order to provide a level plain ground for all adolescents to learn irrespective of family background and socio-economic status.

\section{References}

1. Ajani OA (2018) Needs for In-service Professional Development of Teachers to Improve Students' Academic Performance in Sub-Saharan Africa. Arts Social Sci J 9: 330.

2. Olaniyan DA, Okemakinde T (2008) Human Capital Theory: Implications for Educational Development. Pakistan Journal of Social Sciences 5: 479-483.

3. Arabsheibani G (1988) Educational Choice and Achievement: The Case of Secondary Schools in the Arab Republic of Egypt. Higher Education 17: 637-646.

4. Arum R (1996) Do Private Schools Force Public Schools to Compete? American Sociological Review 61: 29-46.

5. Baker A (1996) Parents as school partners. Final Report. New York, NY: National Council of Jewish Women.

6. Bast JL, Walberg HJ (2004) Can parents choose the best schools for their children? Economics of Education Review 23: 431-440.

7. Bibby J, Peil M (1974) Secondary Education in Ghana: Private Enterprise and Social Selection. Sociology of Education 47: 399-418.

8. Billiton C, Nie W (2009) The customer value proposition should drive supply chain design: An example in mass retailing. Perspectives for Managers 177: 1-4.

9. Bloemer J, de Ruyter K, Wetzels M (1999) Linking perceived service quality and service loyalty: A multi-dimensional perspective. European Journal of Marketing 33: 1082-1106.

10. Coffey A, Atkinson P (1996) Making sense of qualitative data. Complementary research strategies. Thousand Oaks: CA: Sage.

11. Corner JP, Haynes NM (1991) Parent involvement in school. An ecologica approach. Elementary School Journal 91: 271-277. 
Citation: Ajani OA, Dosunmu S (2018) Significance of Parental Influence on School Growth and Population in African Contexts. Arts Social Sci J 9: 365. doi: 10.4172/2151-6200.1000365

Page 9 of 9

12. Donio J, Massari P, Passiante G (2006) Customer satisfaction and loyalty in a digital environment: An empirical test. Journal of Consumer Marketing 23: 445-457.

13. Dronkers J, Robert P (2003) The Effectiveness of Public and Private Schools from a Comparative Perspective, Working Paper SPS No.2003/13, European University Institute.

14. Eakuru N, Mat NKN (2008) The application of structural equation modelling (SEM) in determining the antecedents of customer loyalty in banks in South Thailand. The Business Review 10: 129-139.

15. Elliott C (2010) Confessions of a frequent-flyer program sceptics. South Florida Sun-Sentinel.

16. Epstein J (1991) Toward a theory of family-school connections: In Hurrelmann American Sociological Review 61: 29-46.

17. Gloman G, Ravikumar B (1992) Public versus Private Investment in Human
Capital: Endogenous Growth and Income Inequality. The Journal of Political Economy 100: 818-834.

18. Hoxby CM (2002) Would School Choice Change the Teaching Profession? The Journal of Human Resources 37: 846-891.

19. Ikoya PO, Ikoya OV (2009) Determinants of Rural-Urban Disparity in Private Sector Participation in the Provision and Management of Education in Nigeria. J Soc Sci 19: 225-231.

20. Lai F, Sadoulet E, Janvry AD (2009) The adverse effects of parents' schoo selection errors on academic achievement: Evidence from the Beijing open enrollment program. Economics of Education Review 28: 485-496.

21. Saporito S, Lareau A (1999) School Selection as a Process: The Multiple Dimensions of Race in Framing Educational Choice. Social Problems 46: 418-439.

22. Wilson FCJ, Arnez NL, Asbury CA (1992) African Americans and Independent Schools: Status, Attainment, and Issues. The Journal of Negro Education 61: 125-137. 